Mr. Allen has added considerably to the interest of his narrative by his illustrations, some of which show striking examples of Georgian art, while others are portraits and sketches which illustrate arms and dress at different periods from contemporary Georgian sources.

\section{British County Flora}

The Comital Flora of the British Isles (Flora Comitalis Britannicae: Fl. Com. Brit.): being the Distribution of British (including a number of Non-Indigenous) Plants throughout the 152 Vice-Counties of Great Britain, Ireland and the Channel Islands, with the Place of Growth, Elevation, World-Distribution, Grade, Chief Synonyms and First Names by which the Plants were recorded as British. By Dr. George Claridge Druce. With an original coloured Map showing the Botanical Vice-Counties presented by William James Patey. Pp. xxxii +407. (Arbroath: T. Buncle and Co., 1932.) $20 s$.

$\mathrm{N}$ his introduction, Dr. Druce gives an account of the work of Hewett Cottrell Watson, who devoted many years of a long life to the study of the geographical distribution of our British plants. Watson divided the country into provinces, subprovinces and counties or vice-counties (112 in number) and also employed terms to indicate altitudinal distribution and the nature of the habitat. His results were collected in two classic works, the "Cybele Britannica" in four volumes (1847-59) with a "Supplement" (1860) and the "Topographical Botany" in two parts (1873-74). A second edition of the last-named was prepared by J. G. Baker and the Rev. W. W. Newbould and two "Supplements" have since been published in the Journal of Botany, the first by Arthur Bennett (1905), the second by Bennett, C. E. Salmon and J. R. Matthews (1929-30). Dr. R. L. Praeger's "Irish Topographical Botany" (1901), with "Supplements" in 1906 and 1929, is authoritative for the Irish counties.

These works together with "Floras of the Channel Islands" by Lester-Garland and Marquand form the basis of the "Comital Flora" in which Dr. Druce essayed to collect in one volume all available information. The plan of the work is as follows: the scientific and popular names of the plant are followed by its more important synonyms; the natural habitat, altitudinal and horizontal distribution according to Watson's vice-counties, are given, and finally the first record of the species as British based mainly on W. A. Clarke's "First Records of British Flowering Plants".

The volume, appearing so shortly after the author's death, is a memorial of his industry and his devotion to the study of our British flora; and is valuable as bringing together much scattered information. Its defects are traceable to the personality of the author, and perhaps also to hasty production, excusable in a man who has completed his four-score years. Dr. Druce was unwilling to merge his own opinions in the compromise involved in the acceptance of generally agreed rules of nomenclature, and the student will find in the pages of the "Flora" familiar plants under unfamiliar names, such as Dondia for Suceda, Juncoides for Luzula, and Savastana for Hierochloe; and whereas botanists in council have 'barred' tautonyms, Dr. Druce uses such com. binations as Meum Meum Druce. A more serious fault is the failure to deal more fully with large and critical genera where the information was ready to hand-as in the case of Rubus in the work of Moyle Rogers and of more recent botanists, and Euphrasia, the British species of which have been treated in detail by Rigsley. The notes on the general geographical distribution of the species are sometimes incomplete-Najas flexilis, for example, is cited as European but occurs also in North America-or even inaccurate; and errors in the records of vice-county distribution are noticeable.

The book is neatly bound and of convenient size for a hand-book; the typography is well arranged and clear; and a large, coloured map indicating the vice-counties in Great Britain and Ireland, included as a folder, is a useful addition. A. B. R.

\section{Experiments on Memory}

Remembering : a Study in Experimental and Social Psychology. By Prof. F. C. Bartlett. (The Cambridge Psychological Library.) Pp. $x+317+3$ plates. (Cambridge: At the University Press, 1932.) 16s. net.

DROF. BARTLETT'S experimental investigation of remembering is to be welcomed as a valuable scientific investigation which, in many ways, breaks new ground. During the years since Ebbinghaus invented the experimental method which makes use of nonsense syllables, it is probable that as much has been discovered by this method as ever will be. On the whole, the results have been disappointing. 